\title{
左官技能者による左官材料のワーカビリティーの印象評価 左官材料のワーカビリティーの評価手法に関する研究（その3） \\ IMPRESSION EVALUATION OF WORKABILITY OF PLASTERING MATERIALS EVALUATED BY PLASTERERS
}

Evaluation method of workability for plastering materials (Part 3)

山﨑尚志*, 橘高義 典**, 三田紀行***

Hisashi YAMASAKI, Yoshinori KITSUTAKA and Noriyuki MITA

This paper presents the impression of the workability of plastering materials evaluated by the skilled plasterers. The sensory test using the cement mortars based on various mixture proportions was carried out in order to obtain fundamental information. The fourteen evaluation items such as viscosity, softness, and tired feeling which might be related to the workability of plastering materials were prepared for the sensory test.

As a result, it was found that the plasterers could react to the differences of mixture proportions sensitively, moreover the ease of troweling and finishability are strongly related to the workability of the plastering materials.

Keywords: Workability, Plastering material, Cement mortar, Plasterer, Sensory test, Factor analysis ワーカビリティー, 左官材料, セメントモルタル, 左官, 官能検查, 因子分析

\section{1.はじめに}

今日の左官材料の多くは、既調合材料の使用により左官工事現場 では水のみが混入され練り混ぜられている。しかし、その練混ぜ水 量は左官作業者のワーカビリティーを重視し調整される場合が多く、 練りあがった材料が所定の性能を満足しない場合も考えられ、その ような問題に対して、著者らは左官材料のワーカビリティーの評価 手法に関するいくつかの試みを行ってきた ${ }^{12) 。}$

著者らの既往の実験では、左官材料のワーカビリティーには材料 の流動特性が影響すると考え、流動特性を評価するため傾斜羽根回 転式粘度計を試作し、その基礎的特性について把握してきた。具体 的には、高吸水性樹脂を水に溶解させたビンガム流体を用いて、傾 斜羽根回転式粘度計における安定した測定条件を検討し、その測定 条件のもと、各種セメント系材料の調合要因が流動特性に及ぼす影 響を検討し、当試験装置の基礎的特性を把握した。しかし既往の実 験は、あくまで傾斜羽根回転式粘度計の基礎的特性を把握したにす ぎず、当試験装置により得られる流動特性值と左官材料のワーカビ リティーの関係は明確ではなく、両者の関係を明らかにするために は、官能検查などを実施し、左官技能者によるワーカビリティーの 印象評価と流動特性の対応が不可欠である。

左官材料のワーカビリティーの印象評価に関する研究は、一部の 研究者らによって既に行われている。例えば、大濱らは左官用鋼繊 維補強モルタルのワーカビリティーに関する官能検査結果について
報告している3)。また難波らは、セメントモルタルを中心とした左官 材料を用いて官能検查を実施し、主成分分析の結果を報告している4)。 伊藤らは、溶融スラグ細骨材の左官用モルタルへの適用性について 検するため、左官技能者による作業性の評価を行っている5)。左官工 事と同様に、床仕上工事、タイル張り工事、またはメーソンリー工 事などにおいても、扱う材料のワーカビリティーについて官能検查 を適用した研究例もある( ${ }^{610)}$ 。これらの既往の研究は、官能検查に よって定量化された情報と、材料の流動特性の関係について十分に 議論されていないものが多い。また本研究では、傾斜羽根回転式粘 度計によるワーカビリティーの評価を試みており、新たに情報を整 備する必要がある。

そこで本研究でも、傾斜羽根回転式粘度計によって得られる流動 特性值と左官材料のワーカビリティーの関係を明らかにするため、 左官技能者による左官材料のワーカビリティーの印象評価に関する 官能検查を実施し、本報では、官能検查によって得た左官材料のワ 一カビリティーに関する基礎的な情報として、試料の調合要因がワ 一カビリティーの印象評価に与える影響、各評価項目の相関性や、 多変量解析の結果について報告する。

\section{2. 検查概要}

\section{1 官能検査の概要}

左官作業者がどのような評価基準に基づき左官材料のワーカビリ
* 職業能力開発総合大学校建築システム工学科 助手

** 首都大学東京大学院都市環境科学研究科建築学域 教授. 工博

$* * *$ 職業能力開発総合大学校建築システム工学科 講師・博士 (工学)
Research Assoc., Dept. of Architectural System Eng., Polytechnic Univ.

Prof., Dept. of Architecture and Building Engineering, Graduate School of Environmental Science, Tokyo Metropolitan Univ., Dr. Eng.

Assistant Prof., Dept. of Architectural System Eng., Polytechnic Univ., Dr. Eng. 
ティーを評価しているのかを検討するため、左官作業の官能検查を 行った。検查で対象とする左官材料はセメントモルタルに限定した。 官能検查は、3 名の一級左官技能士、および職歷 3 年の左官技能者 1 名の計 4 名の左官技能者により、調合を変化させたいくつかのセメン トモルタルのワーカビリティーを、左官ごてを用いて検查用壁面へ 塗りつけながら評価するものである。検查の精度を向上するには、 被験者数は多い方が好ましいが、本官能検查で対象とする左官作業 は、ごく基本的な内容であるため、被験者数は 4 名で十分と判断した。

\section{2 使用材料}

本実験の使用材料を表1に示す。セメントは普通ポルトランドセメ ントとした。細骨材は、既往の研究2)を参考に、珪砂の3〜 7号を用い て、JASS15に基づく粒度種別 $\mathrm{B}$ 種の粒度範囲 ${ }^{11)}$ となるよう粒度調整 したものを使用した。増粘剤(MC)にはメチルセルロースを使用した

検查に使用したセメントモルタルの調合は表2に示寸とおり、水セ メント比、および増粘剤添加量を変化させた計19種類とした。増粘 剤は外割りで添加した。砂セメント比は2.5で一定とした。

検查時のセメントモルタルの練混ぜ方法は、以下の通りとした。 まず、官能検査の $24 \sim 48$ 時間前に、セメント、絶乾状態の細骨材、 および増粘剤を、摚汼翼を設けたポリエチレン製の円筒状密閉容器 に投入し、ミル回転台により5分間擋拌した。その後、官能検查時ま で気温 $20^{\circ} \mathrm{C} の$ 恒温室で保管した。検査時には、最大容量 50 リットル のパン型ミキサーにドライミックスされた材料と、所定量の練混ぜ 水を投入し練り混ぜた。練混ぜ時間は4分間とし、セメントモルタル の練混ぜ量は、各サンプルとも22リットルとした。

\section{3 検査方法}

\section{3. 1 評価項目と尺度構成}

本検査は左官材料のワーカビリティーを評価するものであり、検 查に用いる評価項目は、左官材料のワーカビリティーの評価に関連 したものである必要がある。本官能検查で用いた評価項目は表3に示 寸14項目である。むろん、左官材料のワーカビリティーと関連する 評価項目は、この14項目の限りではない(3) 5)。しかし、被験者の疲 労や検査の簡便さを考慮する上で、評価項目数は少ない方が好まし

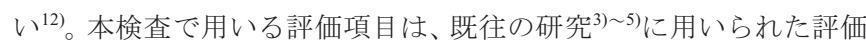
項目や、左官技能者らにより提示された左官材料のワーカビリティ 一を反映しうるキーワードから選定したものである。これらの評価 項目は、本検查での被験者にとって常用的な用語でない場合も考え られる。従って、各評価項目について共通認識を得るため、検査の 前に被験者に対し評価項目の説明を行った。一部補足すると、「少 クい感じ」は、本検查では左官材料中の砂分に関する項目と説明し、 砂分が少ないと感じた場合「あまい」、砂分が多いと感じた場合「か らい」と表現し、一般的にはあまい材料が好まれる。また、「塗り や寸さ」はワーカビリティーの総合評価と説明した。各評価項目は、 -3〜+3の7段階の尺度にもとづき評価し、「塗りやすさ」は-4〜+4の 9段階の尺度構成とした。検查時は、被験者は左官作業に集中し円滑 に評価が行えるよう、各被験者につき補佐員を設け補佐員が被験者 に各評価項目について質問を繰り返すという手順で検查を進めた。

\section{3.2 検査用下地}

本官能検查に用いた下地を図1に示す。検查に使用する塗りつけ下 地は幅 $900 \mathrm{~mm}$ 、高さ $700 \mathrm{~mm}$ とし、幅 $900 \mathrm{~mm}$ 、高さ $1800 \mathrm{~mm}$ 、奥行 き $900 \mathrm{~mm}$ の立方体の2面に設けた。左官作業の官能検查では、塗りつ
表1 使用材料

\begin{tabular}{|c|c|c|c|c|c|c|c|c|}
\hline セメント(C) & \multicolumn{8}{|c|}{ 普通ポルトランドセメント:密度 $3.16 \mathrm{~g} / \mathrm{cm}^{3}, 4$ 週圧縮強度 $63.6 \mathrm{~N} / \mathrm{mm}^{2}$ ブレーン値 $3.300 \mathrm{~cm}^{2} / \mathrm{g}$} \\
\hline \multirow{5}{*}{ 細骨材(S) } & \multicolumn{8}{|c|}{ 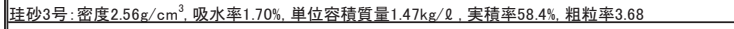 } \\
\hline & \multicolumn{8}{|c|}{ 珪砂 4 号: 密度 $2.57 \mathrm{~g} / \mathrm{cm}^{3}$ ，吸水率 $1.41 \%$ ，単位容積質量 $1.45 \mathrm{~kg} / \mathrm{l}$ ，実積率 $57.0 \%$ ，粗粒率3.00 } \\
\hline & \multicolumn{8}{|c|}{ 这砂5号: 密度 $2.57 \mathrm{~g} / \mathrm{cm}^{3}$ ，吸水率 $1.63 \%$ ，単位容積質量 $1.45 \mathrm{~kg} /$ / ，英積率 $57.7 \%$ ，粗粒率 2.45} \\
\hline & \multirow{2}{*}{\multicolumn{8}{|c|}{ 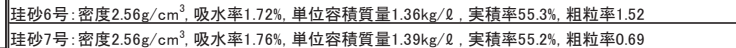 }} \\
\hline & & & & & & & & \\
\hline 増粘䍑(MC) & \multicolumn{8}{|c|}{ メチルセルロース } \\
\hline \multicolumn{9}{|c|}{ 表2 セメントモルタルの調合および試料の提示順序 } \\
\hline \multirow{2}{*}{ 調合№. } & \multirow{2}{*}{$\mathrm{s} / \mathrm{c}$} & \multirow{2}{*}{$\mathrm{W} / \mathrm{C}(\%)$} & \multirow{2}{*}{$\mathrm{MC} / \mathrm{C}(\%)$} & \multicolumn{4}{|c|}{ 単位量 $\left(\mathrm{kg} / \mathrm{m}^{3}\right)$} & 提示 \\
\hline & & & & $\mathrm{C}$ & $\mathrm{s}$ & $\mathrm{W}$ & MC & \\
\hline $48-0$ & \multirow{19}{*}{2.5} & \multirow{3}{*}{48} & 0.0 & 2543 & 1357 & 260 & 0.0 & 6 \\
\hline $48-0.2$ & & & 0.2 & 543 & 1357 & 260 & 1.1 & 14 \\
\hline $48-0.4$ & & & 0.4 & 543 & 1357 & 260 & 2.2 & 17 \\
\hline $50-0$ & & \multirow{4}{*}{50} & 0.0 & 537 & 1341 & 268 & 0.0 & 7 \\
\hline $50-0.1$ & & & 0.1 & 537 & 1341 & 268 & 0.5 & 10 \\
\hline $50-0.2$ & & & 0.2 & 537 & 1341 & 268 & 1.1 & 2 \\
\hline $50-0.4$ & & & 0.4 & 537 & 1341 & 268 & 2.1 & 9 \\
\hline $53-0$ & & \multirow{5}{*}{53} & 0.0 & 528 & 1319 & 280 & 0.0 & 3 \\
\hline $53-0.1$ & & & 0.1 & 528 & 1319 & 280 & 0.5 & 15 \\
\hline $53-0.2$ & & & 0.2 & 528 & 1319 & 280 & 1.1 & 5 \\
\hline $53-0.4$ & & & 0.4 & 528 & 1319 & 280 & 2.1 & 13 \\
\hline $53-0.6$ & & & 0.6 & 528 & 1319 & 280 & 3.2 & 19 \\
\hline $56-0$ & & \multirow{4}{*}{56} & 0.0 & 519 & 1298 & 291 & 0.0 & 4 \\
\hline $56-0.1$ & & & 0.1 & 519 & 1298 & 291 & 0.5 & 8 \\
\hline \begin{tabular}{|c|}
$56-0.2$ \\
\end{tabular} & & & 0.2 & 519 & 1298 & 291 & 1.0 & 11 \\
\hline $56-0.4$ & & & 0.4 & 519 & 1298 & 291 & 2.1 & 16 \\
\hline $59-0$ & & \multirow{3}{*}{59} & 0.0 & 511 & 1277 & 301 & 0.0 & 1 \\
\hline $59-0.2$ & & & 0.2 & 511 & 1277 & 301 & 1.0 & 12 \\
\hline $59-0.4$ & & & 0.4 & 511 & 1277 & 301 & 2.0 & 18 \\
\hline
\end{tabular}

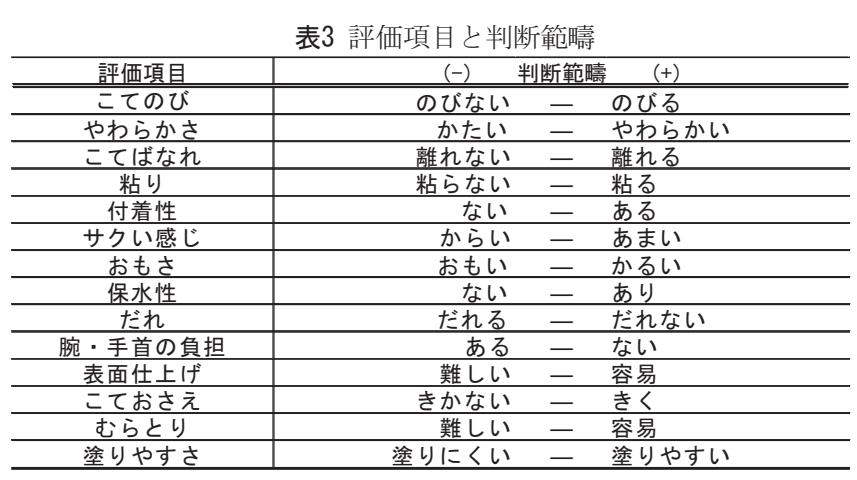

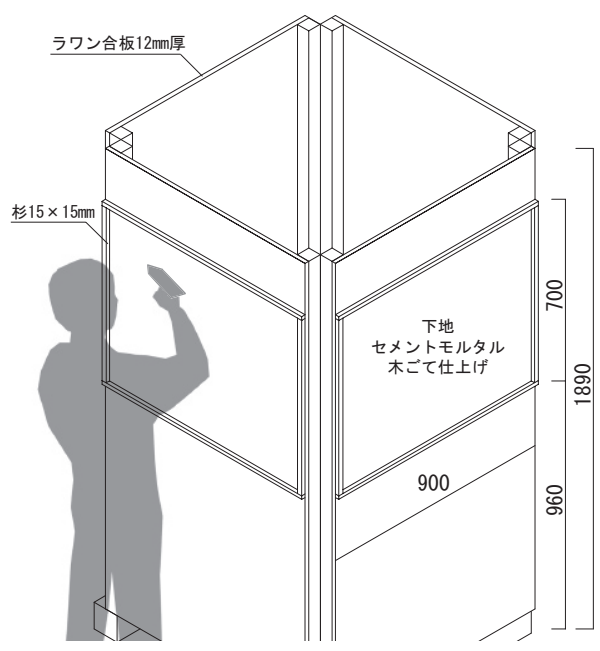

図1 検查用下地

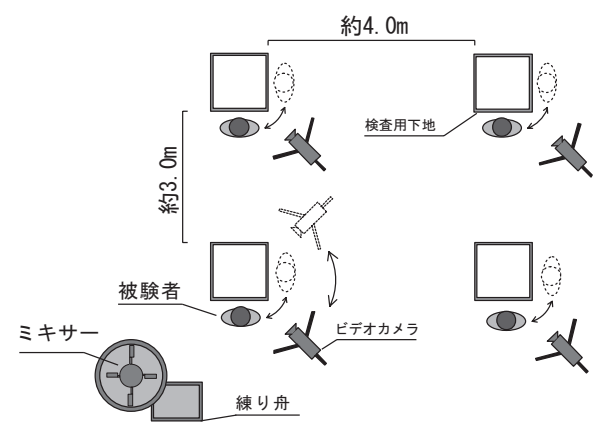

図2 官能検查の環境 
け下地はワーカビリティーの評価に大きく影響するため十分な検討 が必要である。大濱らは、JIS A 5524(1981年時)に規定するラスシー 卜(板厚：0.25mm)を下地材としている3)。また、難波ら、伊藤らは、 コンクリート下地を使用し官能検查を行っている ${ }^{45)}$ 。本官能検查で 用いる下地材は、予好著者らおよび左官技能者によって検討し、セ メントモルタル木ごて仕上げ下地とした。下地材に用いたセメント モルタルは、 $\mathrm{W} / \mathrm{C}=60 \% 、 \mathrm{~S} / \mathrm{C}=3.0 、 \mathrm{MC} / \mathrm{C}=0.2 \%$ の調合のセメントモル タルを平ラス下地へ塗りつけ、28日間以上散水養生し十分に硬化し たものを用いた。検查を行う際は、下地に十分含水させ固く絞った 布を用いて表面に付着した水を拭き取り、下地材がいわゆる表面乾 燥飽水状態となるよう調整した。下地の吸水調整はサンプルごとに 補佐員が行い、サンプルごとの下地の含水状態に差が生じないよう 努めた。被験者は、1つのサンプルの評価が終了したら隣の壁面へ移 動し、続いて次のサンプルについて評価するといった一連の作業を 繰り返した。1サンプルあたりの評価に要する時間は、5分程度を目 安とし、被験者の疲労を考慮し60分ごとに 15 分間の休锶を設けた。 検査は図2に示寸環境で4名同時に行った。検查の様子を写真 1 に示す。 検査時の試料の提示順序は、表2のとおり無作為に提示した。

\section{3. 結果および考察}

\section{1 調合要因と評定值の関係}

各評価項目の評定值を表4に示寸。これらの評定値は4人の被験者 らの評定值の平均值である。まずは、評定值とセメントモルタルの 調合要因の関係を検討する。基本的には、被験者らは各種セメント モルタルの調合要因の変化を概ね捉えていたが、ここでは顕著な傾 向を示したものについてのみ図3から図8に示寸。図3から図5は水セ メント比の影響が著しく見られた「こてのび」、「やわらかさ」、お よび「腕・手首の負担」について示しており、図6から図8は増粘剤添 加量の影響が著しかった「こてばなれ」、「粘り」、および「こてお さえ」について示す。まず図3より、水セメント比の増加につれ「こ てのび」が"のびる"と評価され、また、「腕・手首の負担」について は図5より、水セメント比の増加につれ腕・手首の負担が"ない"と評 価される傾向にある。これは、図4に示寸水セメント比と「やわらか さ」の関係において水セメント比の増加に伴い"やわらかい"と評価

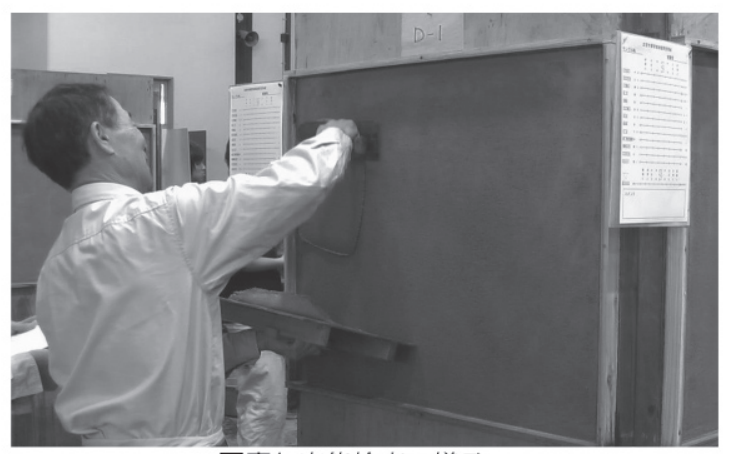

写真1 官能検查の様子

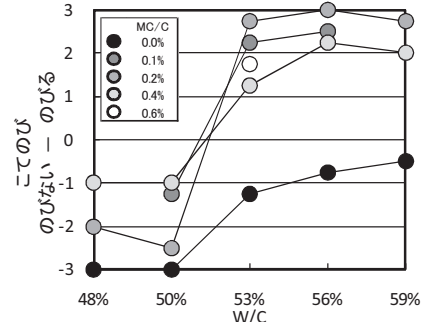

図3 W/Cとこてのび

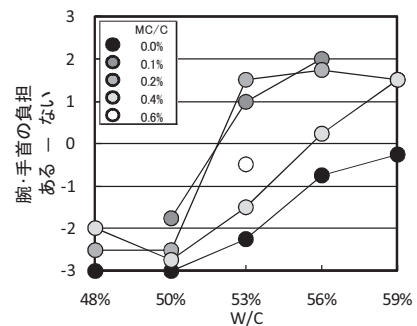

図5 WC/Cと腕・手首の負担

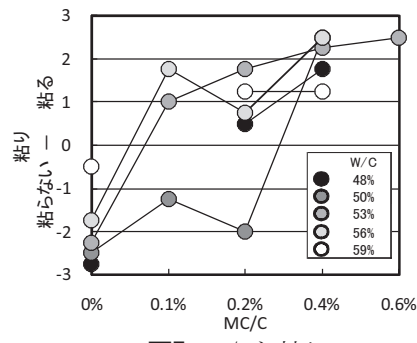

図7 $\mathrm{MC} / \mathrm{C}$ と粘り

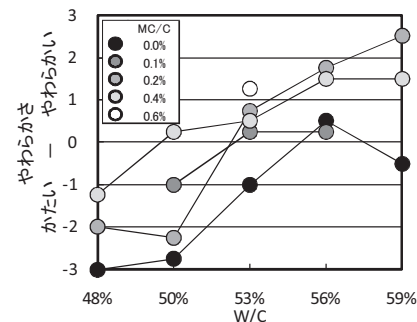

図4 W/Cとやわらかさ

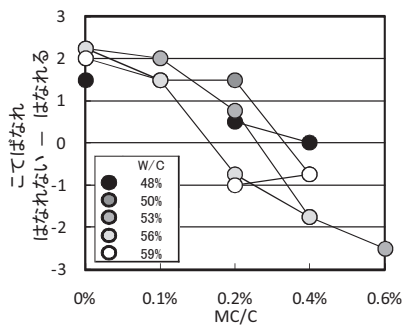

図6 MC/Cとこてばなれ

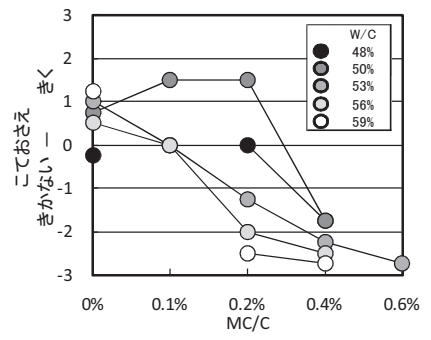

図8 MC/Cとこておさえ

表4各評価項目の評定値

\begin{tabular}{|c|c|c|c|c|c|c|c|c|c|c|c|c|c|c|c|c|}
\hline 調合NNo. & $\begin{array}{l}\begin{array}{c}\text { /C } \\
(\%)\end{array} \\
\end{array}$ & $\begin{array}{c}\text { MC/C } \\
(\%)\end{array}$ & こてのび & やわらかさ & こてばなれ & 粘り & 付着性 & サクい感じ & おもさ & 保水性 & だれ & $\begin{array}{l}\text { 腕·手首の } \\
\text { 負担 }\end{array}$ & 表面仕上げ & こておさえ & むらとり & 塗りやすさ \\
\hline $48-0$ & \multirow{3}{*}{48} & 0.0 & $-3.00(0.00)$ & $-3.00(0.00)$ & $1.50(2.06)$ & $-2.75(0.43)$ & $-2.75(0.43)$ & $-2.50(0.87)$ & $-1.25(0.83)$ & $-2.00(0.71)$ & $2.75(0.43)$ & $-3.00(0.00)$ & $-0.25(2.77)$ & $-0.25(2.77)$ & $-1.25(2.05)$ & $-3.50(0.50)$ \\
\hline $48-0.2$ & & 0.2 & $-2.00(0.71)$ & $-2.00(0.71)$ & $0.50(1.66)$ & $0.50(0.87)$ & $-1.50(0.87)$ & $-0.75(0.43)$ & $-1.25(0.83)$ & $0.25(1.79)$ & $2.25(0.83)$ & $-2.50(0.50)$ & $-0.25(2.28)$ & $0.00(2.12)$ & $2.00(0.71)$ & $-3.00(1.00)$ \\
\hline $48-0.4$ & & 0.4 & $-1.00(1.22)$ & $-1.25(1.09)$ & $0.00(1.22)$ & $1.75(1.09)$ & $0.25(0.83)$ & $-1.25(1.09)$ & $-1.00(0.71)$ & $1.00(0.71)$ & $2.25(0.83)$ & $-2.00(0.71)$ & $-2.00(0.71)$ & $-1.75(1.64)$ & $-1.50(0.87)$ & $-1.75(0.83)$ \\
\hline $50-0$ & \multirow{4}{*}{50} & 0.0 & $-3.00(1.09)$ & $-2.75(0.43)$ & $2.00(0.71)$ & $-2.5(0.50)$ & $-2.50(0.50)$ & $-2.00(1.73)$ & $-1.50(1.12)$ & $-2.00(1.00)$ & $2.75(0.43)$ & $-3.00(0.00)$ & $-0.75(2.28)$ & $0.75(2.28)$ & $-0.75(2.28)$ & $-3.50(0.50)$ \\
\hline 50-0.1 & & 0.1 & $-1.25(0.50)$ & $-1.00(1.41)$ & $1.50(1.12)$ & $-1.25(1.09)$ & $-1.00(0.71)$ & $-1.25(1.09)$ & $-0.75(0.43)$ & $0.25(1.09)$ & $2.25(0.83)$ & $-1.75(0.83)$ & $2.00(0.71)$ & $1.50(1.50)$ & $2.00(0.71)$ & $-0.25(1.92)$ \\
\hline $50-0.2$ & & 0.2 & $-2.50(0.50)$ & $-2.25(0.43)$ & $1.50(1.50)$ & $-2.00(0.00)$ & $-1.50(0.50)$ & $-1.50(0.87)$ & $-1.25(1.30)$ & $-1.25(1.30)$ & $2.00(0.71)$ & $-2.50(0.50)$ & $0.75(1.64)$ & $1.50(0.50)$ & $0.25(0.83)$ & $-2.25(0.43)$ \\
\hline 50-0.4 & & 0.4 & $-1.00(1.22)$ & $0.25(1.09)$ & $-0.75(1.64)$ & $2.50(0.50)$ & $0.00(1.87)$ & $0.50(1.12)$ & $-0.75(0.83)$ & $0.50(2.06)$ & $1.75(0.83)$ & $-2.75(0.43)$ & $-2.00(0.71)$ & $-1.75(1.64)$ & $0.50(1.80)$ & $-2.25(1.48)$ \\
\hline 53-0 & \multirow{5}{*}{53} & 0.0 & $-1.25(1.30)$ & $-1.00(1.41)$ & $2.25(0.43)$ & $-2.25(0.83)$ & $-1.75(0.83)$ & $-1.75(0.83)$ & $-1.25(1.30)$ & $0.50(1.80)$ & $2.00(0.71)$ & $-2.25(0.83)$ & $-0.25(0.43)$ & $1.00(1.22)$ & $-0.75(1.48)$ & $-2.00(0.71)$ \\
\hline 53-0.1 & & 0.1 & $2.25(0.43)$ & $0.25(0.83)$ & $2.00(1.22)$ & $1.00(0.71)$ & $1.50(0.87)$ & $-0.50(0.50)$ & $-0.25(0.43)$ & $0.75(0.83)$ & $1.50(1.50)$ & $1.00(1.22)$ & $0.75(2.17)$ & $0.00(2.12)$ & $1.00(1.22)$ & $2.25(0.43)$ \\
\hline $53-0.2$ & & 0.2 & $2.75(0.43)$ & $0.75(0.83)$ & $0.75(0.83)$ & $1.75(1.09)$ & $2.00(0.00)$ & $0.25(1.09)$ & $0.50(0.87)$ & $2.25(0.43)$ & $0.25(1.79)$ & $1.50(1.50)$ & $-1.25(0.43)$ & $-1.25(1.48)$ & $-0.50(2.06)$ & $2.25(1.09)$ \\
\hline 53-0.4 & & 0.4 & $1.25(1.30)$ & $0.50(1.12)$ & $-1.75(0.83)$ & $2.25(0.43)$ & $0.50(1.66)$ & $0.50(1.12)$ & $-1.00(0.71)$ & $2.00(0.71)$ & $0.50(2.06)$ & $-1.50(0.50)$ & $-2.25(0.43)$ & $-2.25(0.43)$ & $-2.25(0.43)$ & $-0.75(1.30)$ \\
\hline 53-0.6 & & 0.6 & $1.75(1.09)$ & $1.25(1.30)$ & $-2.5(0.50)$ & $2.50(0.50)$ & $1.00(1.22)$ & $0.75(0.83)$ & $-0.75(0.83)$ & $2.75(0.43)$ & $1.25(1.48)$ & $-0.50(2.06)$ & $-2.75(0.43)$ & $-2.75(0.43)$ & $-2.75(0.43)$ & $\begin{array}{lll}-1.75 & 0.830\end{array}$ \\
\hline $56-0$ & & 0.0 & $-0.75(1.79)$ & $0.50(1.12)$ & $2.25(0.43)$ & $-1.75(0.43)$ & $0.25(1.79)$ & $-0.25(1.79)$ & $-0.50(1.12)$ & $1.00(1.73)$ & $2.50(0.87)$ & $-0.75(1.79)$ & $1.25(0.43)$ & $0.50(1.50)$ & $1.00(1.22)$ & $-0.75(1.79)$ \\
\hline $56-0.1$ & & 0.1 & $2.50(0.50)$ & $0.25(0.43)$ & $1.50(1.50)$ & $1.75(1.09)$ & $2.50(0.50)$ & $0.75(0.83)$ & $0.50(0.50)$ & $2.25(0.43)$ & $1.50(2.06)$ & $2.00(0.71)$ & $0.00(1.58)$ & $0.00(1.58)$ & $0.50(2.06)$ & $2.25(0.43)$ \\
\hline $56-0.2$ & & 0.2 & $3.00(0.00)$ & $1.75(1.30)$ & $-0.75(1.09)$ & $0.75(0.43)$ & $2.00(0.71)$ & $1.00(1.58)$ & $0.00(0.71)$ & $1.50(0.50)$ & $-0.75(1.79)$ & $1.75(0.83)$ & $-2.00(0.71)$ & $-2.00(0.71)$ & $-1.50(1.50)$ & $0.75(1.79)$ \\
\hline $56-0.4$ & & 0.4 & $2.25(0.83)$ & $1.50(1.12)$ & $-1.75(0.83)$ & $2.50(0.50)$ & $1.00(1.41)$ & $0.75(1.48)$ & $-0.25(0.83)$ & $2.50(0.50)$ & $0.00(2.12)$ & $0.25(1.30)$ & $-2.50(0.50)$ & $-2.50(0.50)$ & $-2.50(0.50)$ & $-1.50(0.87)$ \\
\hline $59-0$ & & 0.0 & $-0.50(0.87)$ & $-0.50(0.87)$ & $2.00(0.71)$ & $-0.50(1.12)$ & $1.50(1.66)$ & $-0.50(0.87)$ & $0.25(2.38)$ & $0.75(1.30)$ & $2.00(1.22)$ & $-0.25(1.92)$ & $-0.25(1.30)$ & $1.25(0.83)$ & $0.00(1.22)$ & $0.25(0.43)$ \\
\hline 59-0.2 & & 0.2 & $2.75(0.43)$ & $2.50(0.50)$ & $-1.00(1.87)$ & $1.25(1.48)$ & $2.00(0.71)$ & $1.00(0.71)$ & $0.75(1.30)$ & $2.50(0.50)$ & $-1.50(0.87)$ & $1.50(1.50)$ & $-2.50(0.87)$ & $-2.50(0.87)$ & $-2.50(0.87)$ & $0.50(2.18)$ \\
\hline 59-0.4 & & 0.4 & $2.00(071)$ & $1.50(0.50)$ & $-0.75(1.09)$ & $1.25(1.48)$ & $1.75(0.83)$ & $0.50(1.12)$ & $1.00(0.71)$ & $2.25(0.83)$ & $-0.25(2.77)$ & $1.50(1.50)$ & $-2.50(0.50)$ & $-2.75(0.43)$ & $-2.50(0.50)$ & $-0.50(1.80)$ \\
\hline
\end{tabular}


されていることから、水セメント比の増加につれセメントモルタル の軟度がやわらかくなり、材料の可塑性が増したためと考えられる。 一方、増粘剤添加量の影響は、図6より、増粘剤添加量の増加につれ、

「こてばなれ」が"離れない"と評価され、また図 8 より、「こておさ え」が"きかない"と評価されている。これは、図7の増粘剤添加量と 「粘り」の関係からもわかるとおり、増粘剤添加量が増すにつれ" 粘る"と評価されていることから、増粘剤添加量の増加により材料の 粘性が増し、左官ごてに付着しや寸くなったためと考えられる。

\section{2 評価項目の相関分析}

ここでは、官能検查に用いた14種類の評価項目の相関性を検討す る。検查に用いた評価項目のうち、「粘り」および「やわらかさ」

は、材料の流動特性を評価したものといえる。一方、他の評価項目 は、左官作業時の塗りつけ作業に基づき、左官作業に特化した表現 といえる。よってここでは、前者の評価項目を「流動特性評価項目」、 後者の評価項目を「左官作業評価項目」と称し検討を進める。なお、

「塗りやすさ」はワーカビリティーの総合評価であるためこれらの 項目から除外した。

各評価項目間の単相関係数の一覧を表 5 に示す。左官作業評価項目 のうち「むらとり」を除く全ての評価項目は、流動特性評価項目の 「やわらかさ」あるいは「粘り」との相関性が、危険率 $1 \%$ で有意で あることが確認できる。

左官作業評価項目のうち、「こてのび」、「付着性」、「サクい感 じ」、「おもさ」、「保水性」、「だれ」および「腕・手首の負担」は、 流動特性評価項目の「やわらかさ」との単相関係数は、「粘り」と の単相関係数に比べ比較的高い值を示しており、「やわらかさ」と 強い相関関係にあることが推察できる。一方、左官作業評価項目の うち「こてばなれ」、「表面仕上げ」、および「こておさえ」は、流 動特性評価項目のうち「粘り」との相関性が認められる。「むらと り」については、「粘り」および「やわらかさ」との相関はやや弱 いが、「こてばなれ」、「表面仕上げ」、「こておさえ」との相関性 が認められる。

左官材料のワーカビリティーの評価には、本官能検査で用いた評 価項目のような複数の要素が含まれていると考えられるが、それら を総合的に判断し左官材料のワーカビリティーを評価する場合、本 官能検査で用いた「塗りや寸さ」の評価は有効な判断材料となり得
る。従って次に、各評価項目と「塗りやすさ」の相関性について考 察する。各評価項目と「塗りや寸さ」の関係を図9に示す。流動特性 評価項目の「やわらかさ」と強い相関を示した「こてのび」、「付 着性」、「おもさ」および「腕・手首の負担」は、「塗りやすさ」と の単相関係数が $0.77 \sim 0.86$ を示し「塗りや寸さ」と強い相関性が認め られる。一方、流動特性評価項目の「やわらかさ」および「粘り」

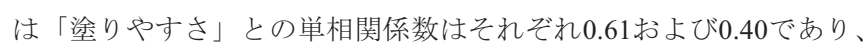
相関が強いとはいえない。単相関係数のみで「やわらかさ」と「塗 りやすさ」の関係を考察すると、材料が軟らかいほど塗りやすいと 解釈できるが、「やわらかさ」と「だれ」の単相関係数が -0.85 を示 している点を踏まえると、材料が軟らかすぎた場合「だれ」が生じ ることが推察できる。また、図9の「やわらかさ」と「塗りやすさ」 の関係を示寸グラフ中の破線で示すように、「やわらかさ」の評定 值が 0 点から +1 点において「塗りやすさ」の評定值が最も高い值を示 すことを考慮すると「やわらかさ」には、特定の適正範囲の存在が 伺える。また、「やわらかさ」の評定值が 0 点から+1点であっても「塗 りやすさ」の評定值が低いものもあり、「塗りやすさ」は、単に「や わらかさ」のみによって評価できないことがわかる。「粘り」と「塗 りやすさ」の相関性がやや弱い理由も同様であり、「こてばなれ」、

「こておさえ」、および「表面仕上げ」が「粘り」と相関性が高い ことを踏まえると、材料が粘りすぎた場合「こてばなれ」が離れに くくなること、「表面仕上げ」が難しくなることや「こておさえ」 がききにくくなると判断できる。また、「粘り」と「塗りやすさ」 の単相関係数は 0.40 と低く、「粘り」のみによって「塗りやすさ」 を評価できないことがわかる。以上より、「塗りや寸さ」は、流動 特性評価項目の「やわらかさ」との単相間、あるいは「粘り」との 単相間のみによって説明することは難しいといえる。

図10は、流動特性評価項目の「やわらかさ」と「粘り」、そして ワーカビリティーの総合評価の「叙りやすさ」の評定值の関係を示 したものである。「塗りやすさ」の評定值が高い材料は、図中の塗 りつぶし部で示すように、「やわらかさ」と「粘り」の関係を示す 座標において、特定の範囲に集中して散布されている様子が確認で き、「やわらかさ」と「粘り」には"塗りやすい"と判断される適度な バランスが存在していると考えられる。また総じてみると、「やわ らかさ」と「粘り」の関係を示寸座標において、塗りつぶし部分か

表5 各評価項目の相関表

\begin{tabular}{|c|c|c|c|c|c|c|c|c|c|c|c|c|c|c|}
\hline & こてのび & やわらかさ & こてばなれ & 粘り & 付着性 & サクい感じ & おもさ & 保水性 & だれ & 腕·手首の負担 & 表面仕上げ & こておさえ & むらとり & 塗りやすさ \\
\hline $\begin{array}{c}\text { こてのび } \\
\text { のびない-のびる }\end{array}$ & 1.00 & $0.90 * *$ & $-0.51 *$ & $0.73 * *$ & $0.92 * *$ & $0.86 * *$ & $0.79 * *$ & $0.88 * *$ & $-0.83 * *$ & $0.92 * *$ & $-0.48 *$ & $-0.64 * *$ & -0.42 & $0.78 * *$ \\
\hline $\begin{array}{c}\text { やわらかさ } \\
\text { かたいーやわらかい }\end{array}$ & - & 1.00 & $-0.61 * *$ & $0.69 * *$ & $0.86 * *$ & $0.92 * *$ & $0.75 * *$ & $0.90 * *$ & $-0.85 * *$ & $0.80 * *$ & $-0.54 *$ & $-0.70 * *$ & $-0.46 *$ & $0.61 * *$ \\
\hline $\begin{array}{c}\text { こてばなれ } \\
\text { 離れない-離れる } \\
\end{array}$ & - & - & 1.00 & $-0.77 * *$ & -0.39 & $-0.68 * *$ & -0.20 & $-0.62 * *$ & $0.65 * *$ & -0.23 & $0.86 * *$ & $0.91 * *$ & $0.69 * *$ & 0.05 \\
\hline $\begin{array}{c}\text { 粘り } \\
\text { 粘らないー粘る }\end{array}$ & - & 二 & - & 1.00 & $0.72 * *$ & $0.82 * *$ & $0.46 *$ & $0.80 * *$ & $-0.58 * *$ & $0.50 *$ & $-0.68 * *$ & $-0.78 * *$ & -0.36 & 0.40 \\
\hline $\begin{array}{c}\text { 付着性 } \\
\text { ない-ある }\end{array}$ & - & - & - & - & 1.00 & $0.86 * *$ & $0.87 * *$ & $0.85 * *$ & $-0.71 * *$ & $0.91 * *$ & -0.39 & $-0.53 *$ & -0.28 & $0.83 * *$ \\
\hline $\begin{array}{c}\text { サクい感じ } \\
\text { からい-あま }\end{array}$ & - & - & - & - & - & 1.00 & $0.69 * *$ & $0.88 * *$ & $-0.78 * *$ & $0.74 * *$ & $-0.57 * *$ & $-0.70 * *$ & -0.36 & $0.56 *$ \\
\hline $\begin{array}{c}\text { おもさ } \\
\text { おもい-かるい }\end{array}$ & - & 二 & - & - & - & - & 1.00 & $0.69 * *$ & $-0.70 * *$ & $0.91 * *$ & -0.28 & -0.39 & -0.24 & $0.77 * *$ \\
\hline $\begin{array}{l}\text { 保水性 } \\
\text { ない-あり } \\
\end{array}$ & - & - & 二 & 二 & - & 二 & - & 1.00 & $-0.72 * *$ & $0.75 * *$ & $-0.54 *$ & $-0.67 * *$ & -0.42 & $0.60 * *$ \\
\hline $\begin{array}{c}\text { だれ } \\
\text { たシれるーだれない }\end{array}$ & - & 二 & 二 & 二 & - & - & - & - & 1.00 & $-0.74 * *$ & $0.65 * *$ & $0.72 * *$ & $0.60 * *$ & $-0.49 *$ \\
\hline $\begin{array}{c}\text { 腕·手首の角担 } \\
\text { あるーない }\end{array}$ & - & - & 二 & - & - & - & - & - & - & 1.00 & -0.26 & -0.41 & -0.27 & $0.86 * *$ \\
\hline $\begin{array}{l}\text { 表面仕上げ } \\
\text { 難しい-容易 } \\
\end{array}$ & - & - & - & - & - & - & 二 & - & - & 二 & 1.00 & $0.91 * *$ & $0.84 * *$ & 0.07 \\
\hline $\begin{array}{l}\text { こておさえ } \\
\text { きかない-きく }\end{array}$ & - & - & - & - & - & - & - & - & - & - & - & 1.00 & $0.75 * *$ & -0.10 \\
\hline $\begin{array}{c}\text { むらとり } \\
\text { 難しい-容易 }\end{array}$ & - & - & - & - & - & - & - & - & - & - & - & - & 1.00 & 0.08 \\
\hline $\begin{array}{c}\text { 塗りやすさ } \\
\text { 余しいー狳りやすい }\end{array}$ & - & - & - & - & - & - & - & - & - & - & - & - & - & 1.00 \\
\hline
\end{tabular}


ら距離が離れるにつれ「塗りやすさ」の評定值が減少していく傾向 がある。以上より、「やわらかさ」および「粘り」の両者のバラン スが適切な場合、左官材料のワーカビリティーは向上寸ると判断で きる。

\section{3 多変量解析による分析}

ここでは、評価項目間の関係をより具体的に把握するため、総合 評価である「塗りやすさ」を除いた評価項目の評定值をもとに因子

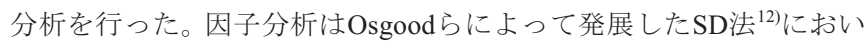
て潜在因子の抽出によく用いられるが、本官能検查においても十分 有意な手法と判断した。因子負荷量の推定には主因子法を用いた。

因子分析の結果を表6に示す。表6には、バリマックス法による因 子軸回転後の因子負荷量を示す。因子分析の結果、2つの潜在因子を 抽出でき、各因子ともに固有值は1.0以上であり、累積寄与率は $80 \%$ 以上を示した。第一因子は、「腕・手首の負担」、「付着性」、「こ てのび」、「おもさ」、「やわらかさ」、「保水性」、「サクい感じ」、 および「だれ」が属しており、主に、左官作業時において材料を壁
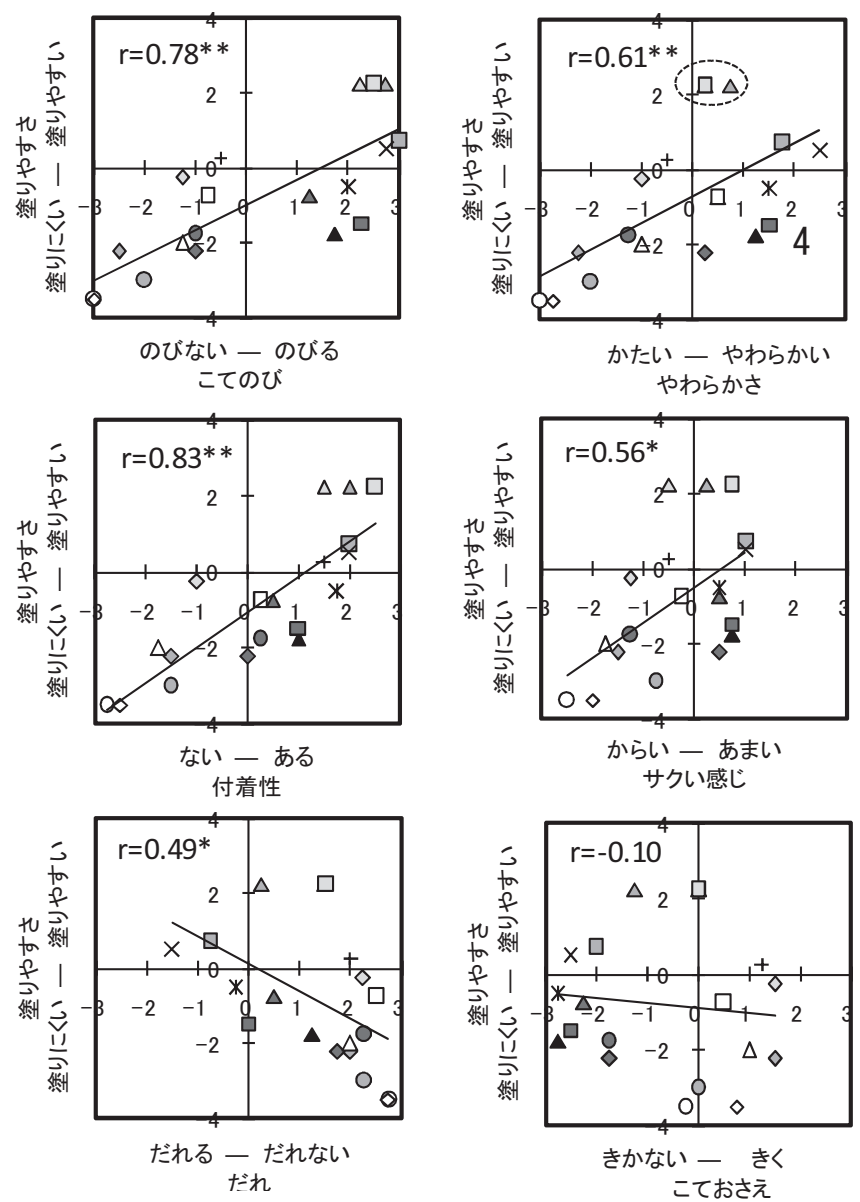

面へ塗りつける時に評価される項目と解勫でき、因子名を「塗りつ け性」とした。第一因子には、流動特性評価項目である「やわらか さ」が属し、その他の評価項目も前節の相関分析において、「やわ らかさ」と相関性を示した評価項目と一致している。一方、第二因 子には、「表面仕上げ」、「こてばなれ」、「こておさえ」、「むらと り」、および「粘り」が属し、主に、左官作業時において材料を壁面 一塗りつけたのち、塗りつけた材料の表面を平滑に仕上げる時に評 価される項目と解釈し、因子名を「仕上げ性」とした。第二因子に は流動特性評価項目の「粘り」が属し、他の評価項目のうち「むら とり」を除いた他の3つの評価項目は、前節での相関分析において「粘 り」と相関性が強かった評価項目と一致している。

以上の因子分析結果に加え、前節での相関分析の結果も考慮する

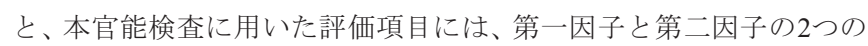
潜在因子が存在し、「やわらかさ」の影響を受けやすい第一因子に 属するものと、「粘り」の影響を受けやすい第二因子に属するもの に大別できる。最後に、これらの潜在因子が左官材料のワーカビリ

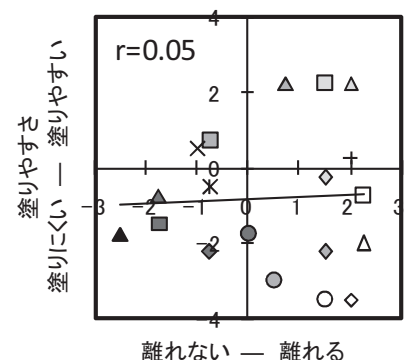

こてばなれ
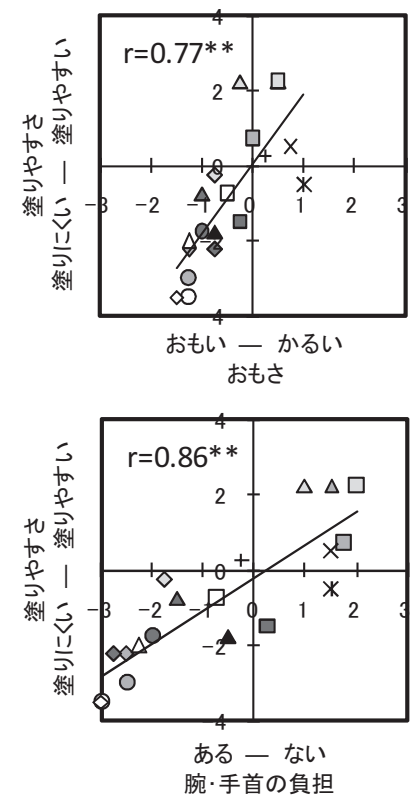

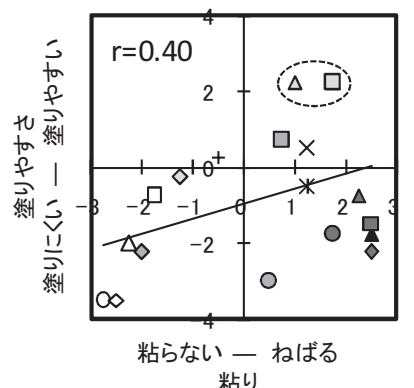

粘り
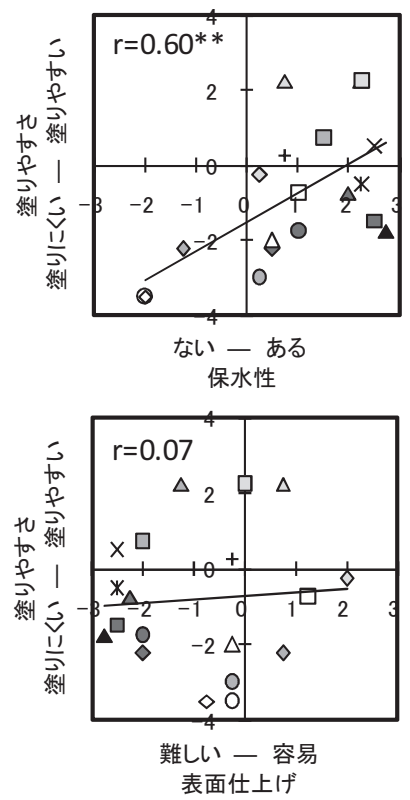

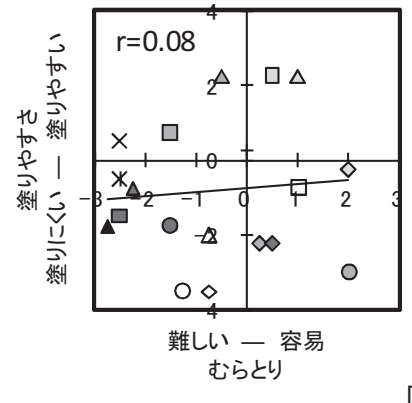

表 2 中の調合№.

\begin{tabular}{|cccccccccc|}
\hline$\bigcirc$ & $48-0$ & $\searrow$ & $50-0$ & $\triangle$ & $53-0$ & $\square$ & $56-0$ & + & $59-0$ \\
$\bigcirc$ & $48-0.2$ & $\searrow$ & $50-0.1$ & $\triangle$ & $53-0.1$ & $\square$ & $56-0.1$ & $\times$ & $59-0.2$ \\
$\bigcirc$ & $48-0.4$ & $\searrow$ & $50-0.2$ & $\triangle$ & $53-0.2$ & $\square$ & $56-0.2$ & $*$ & $59-0.4$ \\
& & $\diamond$ & $50-0.4$ & $\triangle$ & $53-0.4$ & $\square$ & $56-0.4$ & & \\
& & & & $\triangle$ & $53-0.6$ & & & & \\
\hline
\end{tabular}

図9 各評価項目と।塗りやすさ」の関係 
ティーの評価にどの程度影響しているのかを検討するため、各因子 の因子得点を説明変数、ワーカビリティーの総合評価である「塗り や寸さ」の評定值を目的変数とし重回帰分析を行った。

重回帰分析の結果は表7に示すとおりである。表7より、決定係数

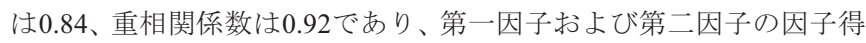
点により、「塗りや寸さ」をよく説明できている。第一因子の標準 偏回帰係数は 0.90 、第二因子の標準偏回帰係数は 0.16 であり、本検査 結果では左官材料のワーカビリティーの評価には、基本的には第一 因子の影響が大きく、第二因子の影響は比較的小さいことがわかる。

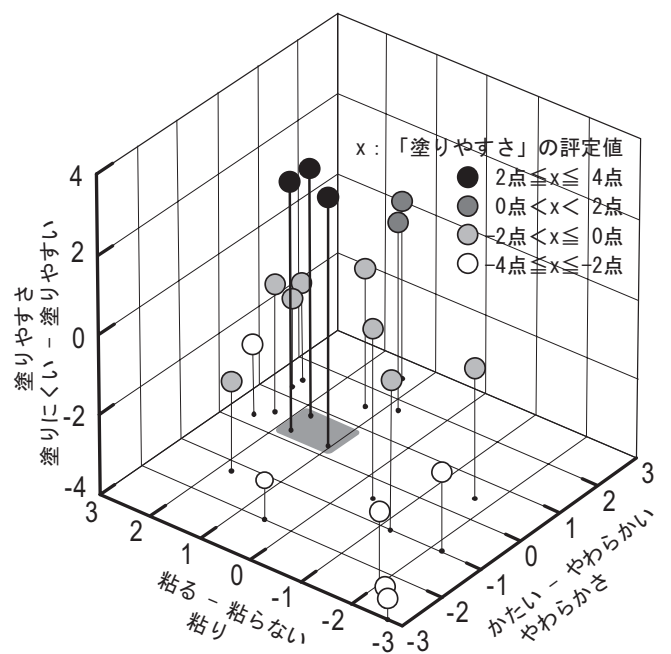

図 10 「やわらかさ、「粘り」と「塗りや寸さ」の関係

\begin{tabular}{c|c|c}
\multicolumn{3}{c}{ 表6 因子分析結果 } \\
\hline & 第一因子 & 第二因子 \\
\hline 腕·手首の負担 & 0.957 & -0.074 \\
付着性 & 0.944 & -0.219 \\
こてのび & 0.901 & -0.357 \\
おもさ & 0.882 & -0.074 \\
やわらかさ & 0.829 & -0.454 \\
保水性 & 0.786 & -0.462 \\
サクい感゙ & 0.786 & -0.490 \\
だれ & -0.680 & 0.539 \\
\hline 表面仕上げ & -0.178 & 0.938 \\
こてばなれ & -0.212 & 0.929 \\
こておさえ & -0.349 & 0.910 \\
むらとり & -0.145 & 0.740 \\
粘り & 0.545 & -0.613 \\
\hline 固有値 & 6.3 & 4.6 \\
\hline 寄与率(\%) & 48.5 & 35.6 \\
\hline 累積寄与率(\%) & 48.5 & 84.1 \\
\hline 因子名 & 塗りつけ性 & 仕上げ性 \\
\hline \multicolumn{2}{|c}{}
\end{tabular}

表7 重回帰分析結果

\begin{tabular}{c|c|c|c|c|c}
\hline 説明変数名 & 偏回帰係数 & $\begin{array}{c}\text { 標準偏回 } \\
\text { 帰係数 }\end{array}$ & t值 & \multirow{2}{*}{ 決定係数 } & 重相関係数 \\
\hline 第一因子 & 1.67 & 0.90 & 8.92 & & \multirow{2}{*}{0.84} \\
\cline { 1 - 4 } 第二因子 & 0.26 & 0.16 & 1.58 & \multirow{2}{*}{0.92} \\
\cline { 1 - 4 } 定数項 & -0.82 & - & -4.52 & & \\
\hline
\end{tabular}

\section{4.まとめ}

本報では、左官技能者らによる左官材料のワーカビリティーの印 象評価に関する基礎データを得ること目的とし、官能検查を行いそ の結果を報告した。得られた知見を以下にまとめる。

1) 左官技能者らは、調合要因である水セメント比および増粘剤添加 量の変化による流動特性の違いを感覚的にとらえ、水セメント比は
主に、「こてのび」、「やわらかさ」、および「腕・手首の負担」の 評価に影響し、増粘剤添加量は「こてばなれ」、「粘り」、および 「こておさえ」の評価に影響する。

2) 左官材料のワーカビリティーの総合評価である「塗りやすさ」は 流動特性評価項目の「やわらかさ」との単相間、あるいは「粘り」 との単相間によって説明することは難しい。

3）官能検查で用いた評価項目の評定值による因子分析の結果、「塗 りつけ性」および「仕上げ性」と解釈できる2つの潜在因子を抽出し、 「塗りつけ性」は「やわらかさ」の影響を受ける評価項目が属し、 「仕上げ性」は「粘り」の影響を受ける評価項目が属する。

\section{今後の展望}

本報では、左官材料のワーカビリティーの総合評価と定義した「塗 りや寸さ」の評価に、材料の「やわらかさ」と「粘り」が複合的に 影響し、両者には適度なバランスが存在していることが見受けられ た。今後は、「やわらかさ」と「粘り」を特定の物性值により評価 し、物性值と印象評価の関係を明らかにする。

\section{謝辞}

官能検查を行うにあたり、多大なるご支援を賜った日本左官業組合連 合会会長 守屋清氏、また、官能検查に関しご指導を賜った日本左官業組 合連合会理事 鈴木光氏ならびに官能検查被験者としてご協力いただい た、大久保氏、西野氏、諸岡氏、鈴木氏および補佐員として協力いただ いた学生諸君に深く感謝する。また、本研究についてご指導を賜った大 澤清八先生、田村雅紀先生、松沢晃一先生に謝意を表す。

\section{参考文献}

1) 山㠃尚志, 橘高義典, 三田紀行: 傾斜羽根回転式粘度計の基礎的特性 左官材料の ワーカビリティーの評価手法に関する研究(その 1 ), 日本建築学会構造系論文 集, 第632号, pp.1707-1711, 2008.10

2）山㠃尚志, 樀高義典, 三田紀行 : 傾斜羽根回転式粘度計によるセメントモルタル のフレッシュ性状の評価 左官材料のワーカビリティーの評価手法に関する研 究(その 2), 日本建築学会構造系論文集, 第645号, pp.1929-1934, 2009.11

3) 大濱嘉彦, 菅原鉄治, 小玉陽彦 : 左官用綱繊維補強モルタルの作業性, 第3回コン クリート工学年次講演会講演論文集, pp.213-216, 1974.10

4) 難波蓮太郎, 鈴木慶一: 左官工事における作業性能に関する研究 その11 (左官 技能者の定性的材料識別評価の主成分分析結果と斜目加力レオメーターで得ら れた結果間の関連性), 日本建築学会大会学術講演梗概集A-1, pp.599-600, 1987.10

5) 伊藤学, 他8名 : 溶融スラグ細骨材の左官用モルタルへの適用に関する基礎的研 究 その6 溶融スラグ細骨材を用いたモルタルの作業性の検討, 日本建築学会大 会学術講演梗概集(九州)A-1, pp.681-682, 2007.8

6) 本田悟, 椎葉大和 : 高流動コンクリートの床仕上げ作業性に関する研究, コンク リート工学年次論文報告集, Vol.19, No.1, pp.127-132, 1997

7) 久保田憲一,ほか4名: 特殊軽量モルタルを用いたタイル直張り工法の開発 その5 施工実験, 日本建築学会大会学術講演梗概集A-1, pp.1057-1058, 1999.8

8) 佐々木靖, ほか6名 : 外装タイル仕上げ用下地モルタルに関する研究(その1 四半モ ルタルの鏝涂作業性), 日本建築学会学術講演梗概集(近畿)A-1, pp.845-846, 1996.9

9) Roel Hendrickx: : The adequate measurement of the workability of masonry mortar, $\mathrm{PhD}$ thesis, Katholieke Universiteit Leuven, pp.67-91, 2009.10

10) Helmut Strasser, Baoqiu Wang, Adolf Hoffmann: Electromyographic and subjective evaluation of hand tools : The example of masons' trowels, International Journal of Industrial Ergonomics, Vol.18, pp91-106, 1996

11) 日本建築学会 : 建築工事標準仕様書·同解説 JASS15, pp.6-7, 2007.6

12) 岩下豊彦: SD法によるイメージの測定, 川島書店, 1983.1 